\title{
Day Times Picogram per Milliliter
}

National Cancer Institute

\section{Source}

National Cancer Institute. Day Times Picogram per Milliliter. NCI Thesaurus. Code C85593.

Days times picograms per milliliter. 